\title{
Brain nutrients: Cerebral metabolism and micronutrients
}

\author{
Uwe Gröber* \\ Academy of Micronutrient Medicine (AMM), Essen, Germany
}

\begin{abstract}
Optimal cognitive capacity is vital throughout all stages of life. Most notably a healthy nutrition in childhood and adolescence is crucial for brain development and cognitive performance. Micronutrients are an essential component of several general cellular functions as well as of functions to neurologic activity such as the synthesis of dopamine, serotonin, and myelin formation. An adequate dietary supply with brain active micronutrients, such as vitamins, minerals and omega-3 longchain polyunsaturated fatty acids is therefore in schoolchildren of essential significance. The possibilities and limitations to boost the cognitive capacity of children for the purpose of a "brain doping" will be discussed.
\end{abstract}

\begin{abstract}
A healthy diet: A concept foreign to many school children
Despite numerous information campaigns in recent years, there is still a very wide gap between a healthy diet in theory and the actual eating habits of many age groups, especially children and adolescents. This has once again become alarmingly clear from the results of the HELENA study, carried out across Europe on adolescents aged 12.5 to 17.5 years. The multicentre European project was conducted in 10 countries: Belgium (Ghent), Germany (Dortmund), France (Lille), Greece (Athens, Heraklion on Crete), the United Kingdom (Birmingham), Italy (Rome), Austria (Vienna), Hungary (Pécs), Sweden (Stockholm) and Spain (Zaragoza) [1-3].
\end{abstract}

According to the HELENA study, Europe's youth consume a daily average of about $160 \mathrm{~g}$ meat, $125 \mathrm{~g}$ fruit, $100 \mathrm{~g}$ vegetables, $55 \mathrm{~g}$ cake and sweet pastries, $25 \mathrm{~g}$ chocolate, $728 \mathrm{~mL}$ water, $260 \mathrm{~mL}$ milk, and 303 $\mathrm{mL}$ soft drinks sweetened with sugar. The high consumption of luxury foods and sugar-containing soft drinks is sometimes associated with a daily calorie intake of up to $3300 \mathrm{kcal}$ (Table 1) [1-3]. In this context, it is of interest that recent study results confirm that an unhealthy diet of this nature together with overweight is associated with shrinkage of entire areas of the brain (e.g. the hippocampus) and impaired cognitive function in adolescents [4,5]. As a result of the high-energy, but nutrient-poor intake, the total energy consumption of the majority of adolescents is above the age-appropriate optimally balanced diet as recommended by the Research Institute for Child Nutrition (FKE) in Dortmund, Germany. For example, they recommend a daily intake of $2200 \mathrm{kcal}$ for 13- to 14-year-old girls and of $2700 \mathrm{kcal}$ for boys of this age. A greater intake of fruit and vegetables is associated with a greater supply of vitamins (e.g. vitamin C, folic acid), minerals (e.g. calcium, potassium), phytochemicals (e.g. carotenoids) and dietary fibre. It is hardly surprising, therefore, that the number of overweight children in our country is steadily increasing and that many young people do not have an adequate dietary supply of essential vitamins, minerals, longchain omega-3 fatty acids (e.g. eicosapentaenoic acid, docosahexaenoic acid) and other brain nutrients.

\section{Vitamin D for the healthy development of the brain}

A good vitamin D status [25-dihydroxy vitamin D (25(OH)D): 40$60 \mathrm{ng} / \mathrm{mL}$ or $100-150 \mathrm{nmol} / \mathrm{L}$ ] is of key importance to child development and maturation, especially during pregnancy and growth phases.
Table 1. Comparison of the eating habits of adolescents (HELENA study) with the FKE (Research Institute for Child Nutrition) recommendations for an age-appropriate balanced diet $[1,3]$. $\left({ }^{1}\right.$ Age group: 12.5 to 17.5 years; ${ }^{2}$ Age group: 13 to 14 years. ${ }^{3}$ Tolerated foods: according to the FKE, $10 \%$ of the total energy may be covered by tolerated foods. For the age group 13-14 years, this means $\leq 220 / 270 \mathrm{kcal} /$ day $(\mathrm{m} / \mathrm{f})$, i.e. each $100 \mathrm{kcal}=45 \mathrm{~g}$ fruit tart or 4 biscuits or $30 \mathrm{~g}$ fruit gummis or $20 \mathrm{~g}$ chocolate or 10 crisps or 1 glass $(200 \mathrm{~mL})$ of soft drink)

\begin{tabular}{|l|c|c|}
\hline Food & HELENA study $^{\mathbf{1}}$ & Balanced diet (FKE) $^{\mathbf{2}}$ \\
\hline Meat, processed meat (g/day) & 160 & $65 / 75\left(\mathrm{f} / \mathrm{m}^{1}\right)$ \\
\hline Fruit (g/day) & 125 & $260 / 300(\mathrm{f} / \mathrm{m})$ \\
\hline Vegetables (g/day) & 100 & $260 / 300(\mathrm{f} / \mathrm{m})$ \\
\hline Fish (g/week) & 20 & $100 / 100(\mathrm{f} / \mathrm{m})$ \\
\hline Milk, dairy products (mL/day) & 260 & $425 / 450(\mathrm{f} / \mathrm{m})$ \\
\hline Drinks & & \\
\hline Water (mL/day) & 728 & $1200 / 1300(\mathrm{f} / \mathrm{m})$ \\
\hline Soft drinks containing sugar (mL/day) & 303 & 3 \\
\hline Luxury food & & 3 \\
\hline Chocolate (g/day) & 25 & 3 \\
\hline Cakes and sweet pastries (g/day) & 55 & \\
\hline Total energy & & $2200 / 2700(\mathrm{f} / \mathrm{m})^{2}$ \\
\hline kcal/day & up to 3300 & \\
\hline
\end{tabular}

Vitamin $\mathrm{D}$ is therefore particularly important for the development and functioning of the brain. In its hormonally active form $1,25(\mathrm{OH})_{2} \mathrm{D}$, the sunshine vitamin acts as a neurosteroid through its interaction with vitamin $\mathrm{D}$ receptors (VDRs) during neuronal differentiation and maturation, whereby it regulates the production of neurotrophic factors such as glial cell-derived neurotrophic factor (GDNF). 1,25(OH) $\mathrm{D}$ also has a marked neuroprotective effect, in that it inhibits neuronal inflammatory reactions and oxidative processes (Figure 1).

VDRs are expressed in various parts of the brain, including the basal forebrain, the caudate nucleus and putamen, cerebellum, lateral geniculate body, cingulate gyrus, hypothalamus, prefrontal cortex, substantia nigra and the thalamus. The enzyme 25(OH)D 1- alpha

${ }^{\star}$ Correspondence to: Uwe Gröber, Academy of Micronutrient Medicine (AMM), Essen, Germany, E-mail: uwegroeber@gmx.net

Key words: brain, diet, vitamin $D, n-3$ fatty acids, iron, $B$ vitamins

Received: May 21, 2020; Accepted: June 14, 2020; Published: June 17, 2020 


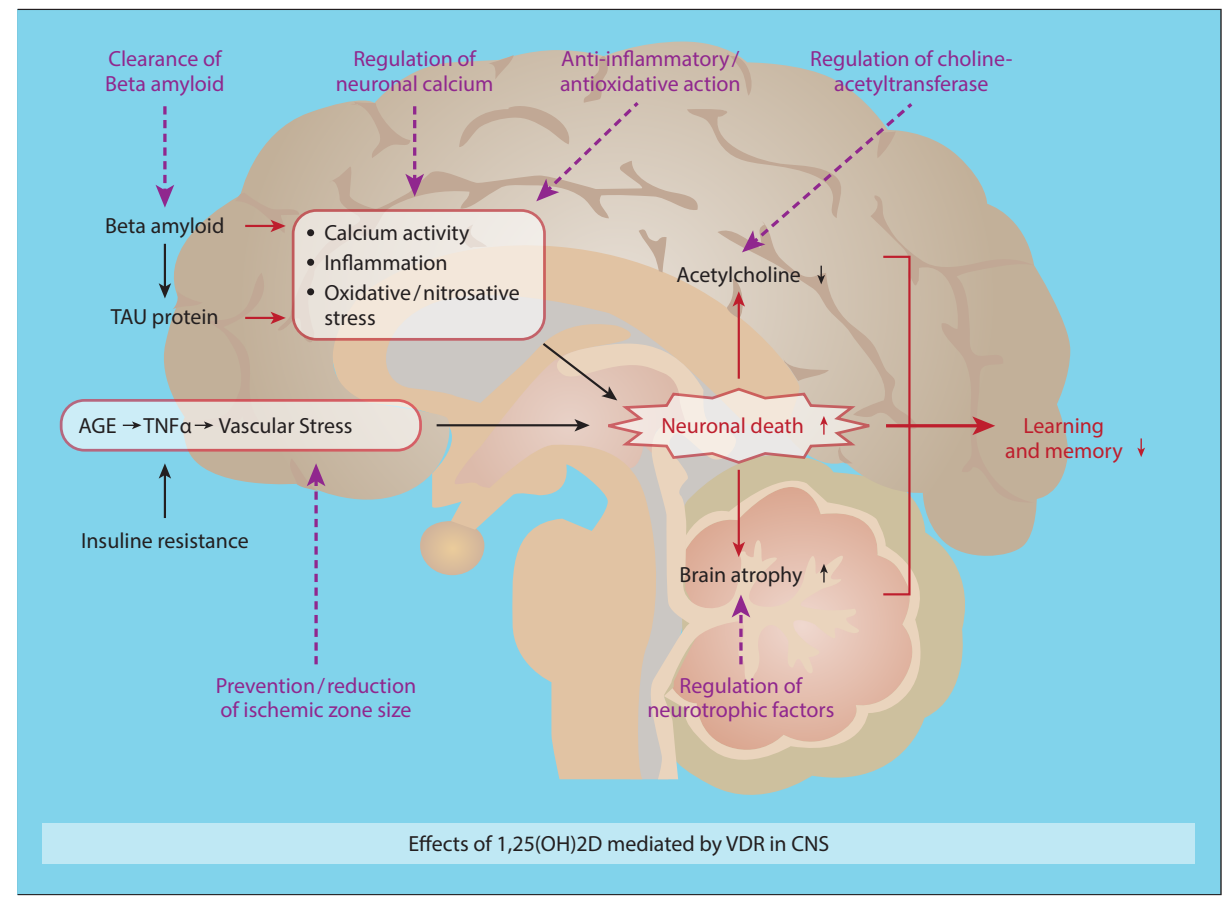

Figure 1. Effects of $1,25(\mathrm{OH}) 2 \mathrm{D}$ mediated by VDR in CNS

hydroxylase, which is responsible for the conversion of $25(\mathrm{OH}) \mathrm{D}$ into its hormonally active form $1,25(\mathrm{OH})_{2} \mathrm{D}$, can be found together with VDRs in many regions of the brain (e.g. the hippocampus). In addition, it has been shown that VDR gene polymorphism is associated with a decline of cognitive function and the risk of neurodegenerative diseases (e.g. Alzheimer's disease) [6-8].

Today we assume that $1,25(\mathrm{OH})_{2} \mathrm{D}$, in interaction with VDRs, regulates more than 2000 of the 20,488 genes in the human genome, either directly or indirectly. Besides disorders of bone mineralisation that may lead to rickets in children and osteomalacia in adults, vitamin $\mathrm{D}$ deficiency (serum $25(\mathrm{OH}) \mathrm{D}<20 \mathrm{ng} / \mathrm{mL}$ ) contributes to the pathogenesis of many chronic diseases. These include autoimmune diseases (e.g. multiple sclerosis), cardiovascular diseases (e.g. high blood pressure, heart failure), cancer and neurodegenerative diseases (e.g. Alzheimer's disease, Parkinson's disease).

The results of large-scale studies have shown that the vitamin D intake of most children and adolescents in Germany is worse than deficient. A representative sample of the child and adolescent health survey (KIGGS) showed that average $25(\mathrm{OH}) \mathrm{D}$ levels in children aged $0-2$ years were $23 \mathrm{ng} / \mathrm{mL}$ in girls and $24.5 \mathrm{ng} / \mathrm{mL}$ in boys. It is particularly alarming that the vitamin D levels in children and adolescents decreases with increasing age. Boys aged 14-17 years and girls aged 11-13 years exhibit the lowest vitamin D levels, with $14.2 \mathrm{ng} / \mathrm{mL}$ and $13.7 \mathrm{ng} / \mathrm{mL}$ respectively. There were also clear seasonal differences in $25(\mathrm{OH}) \mathrm{D}$ levels. The lowest average levels were seen in February $(\rightarrow 10.56 \mathrm{ng} / \mathrm{mL})$ and the highest in August ( $\rightarrow 24.16 \mathrm{ng} / \mathrm{mL}$ ). Children with a migration background had average levels clearly lower than those without such a background (13.4 ng/mL vs $16.7 \mathrm{ng} / \mathrm{mL}$ ). Taking a cut-off of $20 \mathrm{ng} / \mathrm{mL}$ for the $25(\mathrm{OH}) \mathrm{D}$ level, $62 \%$ of the 3 - to 17 -year-old non-immigrants and $76 \%$ of the migrants had a vitamin $\mathrm{D}$ deficiency. Furthermore, as was to be expected, children and adolescents, who were overweight or obese, had clearly lower $25(\mathrm{OH}) \mathrm{D}$ levels than those of normal weight.

The results of the National Consumption Survey II showed that the daily vitamin D intake of $>96 \%$ of girls and $86 \%$ of boys aged $14-18$ years failed to meet the recommendations $[9,10]$. A recent European study, which collected data on the 25(OH)D status of 1006 adolescents aged between 12.5 and 17.5 years, showed that $39 \%$ of them had an inadequate vitamin D status (25(OH)D: $20-30 \mathrm{ng} / \mathrm{mL}), 27 \%$ a vitamin $\mathrm{D}$ deficiency, and $15 \%$ a severe vitamin $\mathrm{D}$ deficiency. In this study, only $19 \%$ had an adequate vitamin $\mathrm{D}$ status of $25(\mathrm{OH}) \mathrm{D} \geq 30 \mathrm{ng} / \mathrm{mL}$. To date, there are no studies on whether vitamin $\mathrm{D}$ supplements in children and adolescents can improve cerebral function to any extent. But we have to assume that children with a vitamin D deficiency [25(OH)D $<20 \mathrm{ng} /$ $\mathrm{mL}$ ] would benefit the most from targeted vitamin $\mathrm{D}$ supplementation with respect to their mental and physical development $[8,9]$.

Recommendation: The results of these studies justify in any case the recommendation to improve the $25(\mathrm{OH}) \mathrm{D}$ status in children and adolescents through a healthy approach with exposure to sunlight, a good supply of vitamin-D-containing foodstuffs and vitamin D supplements. A good vitamin D intake should be ensured as a matter of principle for a healthy immunological, metabolic and neurological development. A healthy $25(\mathrm{OH}) \mathrm{D}$ status is characterised by $25(\mathrm{OH}) \mathrm{D}$ levels of $40-60 \mathrm{ng} / \mathrm{mL}$ or $100-150 \mathrm{nmol} / \mathrm{L}$ for all age groups. As it is not possible to provide an adequate supply of cholecalciferol via the diet and vitamin D can only be produced in Germany during the summer months with the help of sunlight, children and adolescents should be taking about 40-60 IU vitamin D per kg body weight daily in the form of vitamin D supplements.

\section{Cerebral fatty acids: EPA and DHA}

The long-chain polyunsaturated omega-3 fatty acids eicosapentaenoic acid (EPA) and docosahexaenoic acid (DHA) are essential building blocks determining the function of every nerve cell membrane. For example, these fatty acids enhance the conduction of impulses at synapses in the central nervous system (CNS) by increasing neuronal membrane fluidity. In addition, EPA and DHA have an important role in nerve cell differentiation, intercellular communication, synaptogenesis, neurogenesis and gene expression. Lipid mediators derived from the long-chain omega- 3 fatty acids, such as resolvins and 
protectins, have strong anti-inflammatory and neuroprotective actions. In all phases of life - but especially during pregnancy, childhood and adolescence - EPA and DHA are therefore of fundamental importance for the development of the brain and intelligence.

Fatty saltwater fish such as herrings, mackerel, salmon and cod are particularly rich in EPA and DHA. As the HELENA study shows, young people in Europe aged between 12.5 and 17.5 years do not eat enough fish, failing by far to meet the recommended daily intake. More than a third of the adolescents do not even consume the recommended quantity of alpha-linolenic acid (ALA). The regular diet of many adolescents therefore carries a high risk of an insufficient supply of EPA and DHA. Various studies have reported an improvement in cognitive function (e.g. memory, attention) and scholastic performance (e.g. reading, spelling) in schoolchildren taking regular supplements of DHA and EPA [10-12].

\section{Recommendation: When administering omega-3 fatty acids (e.g} omega-3 oil, algae oil), it is extremely important to ensure a regular intake of EPA and DHA at a sufficiently high dose ( 40-50 mg EPA/ DHA per kg body weight per day). As a rule, it takes several months to see the first effects. With respect to cognitive function, children, who have a dietary deficiency of omega- 3 fatty acids, may obtain the greatest benefit from EPA/DHA supplements (e.g. $3000 \mathrm{mg}$ EPA/DHA per day). The HS-Omega-3 Index, which measures the concentrations of EPA and DHA in red blood cell membranes, can be used to assess the individual EPA and DHA status (target value: $\geq 10 \%$ ).

\section{Iron and intelligence}

Besidesitsroleinoxygen transportasa component of thehaemoglobin molecule, iron plays an essential part in the synthesis of nucleic acids (DNA, RNA) and proteins, in cell growth and differentiation as well as in gene expression. In addition, iron is indispensable for the energy metabolism of neurones and glial cells as well as for the production of neurotransmitters (e.g. dopamine, serotonin), synaptogenesis and myelination. Worldwide, iron deficiency is by far the most common trace element deficiency. In Europe, the prevalence of iron deficiency is about $10 \%$ [10]. Iron deficiency may have a negative impact on cognitive function in children. Decreased motor activity, reduced social awareness and poorer scholastic performance have been observed in schoolchildren with anaemia. In general, iron deficiency can cause tiredness and impair performance even in the absence of anaemia. A good supply of iron and vitamins (e.g. vitamin $\mathrm{D}$, vitamin $\mathrm{A}$, vitamin $\mathrm{C}$ ) in adolescents is also an important factor in physical performance (e.g. stamina, muscle strength), because iron is an integral component of the red blood cell pigment haemoglobin, which is responsible for carrying oxygen to the muscles, while antioxidants such as vitamin $\mathrm{C}$ promote regeneration after intensive training and vitamin $\mathrm{D}$ reinforces muscle strength via its interactions with vitamin $\mathrm{D}$ receptors.

There is an increased need for iron during growth phases, which cannot always be covered sufficiently through the diet. Therefore, an inadequate iron intake is often observed among adolescents. According to the results of the National Consumption Survey II, 58\% of girls and $14 \%$ of boys in the 14-18 age group do not achieve the recommended daily intake of iron $[13,14]$. These results have also been confirmed by the recent HELENA study, which looked at the iron status of adolescents from 10 European countries. Serum ferritin levels $(<15 \mu \mathrm{g} / \mathrm{L})$ were taken as the indicator of iron depletion, while soluble transferrin receptor (sTfR) levels $(>8.5 \mathrm{mg} / \mathrm{L})$ together with iron depletion was taken as the indicator of iron deficiency. A serum ferritin level of $<15$ $\mu \mathrm{g} / \mathrm{L}$ is already evidence of depleted iron stores. A latent iron deficiency with non-haematological symptoms may already exist with ferritin levels of $<50 \mu \mathrm{g} / \mathrm{L}$. As inflammatory processes can affect the quality of diagnostic investigations for iron, subjects with high C-reactive protein levels (CRP $>5 \mathrm{mg} / \mathrm{L}$ ) were excluded from the analysis.

Data from 940 adolescents (502 girls, 438 boys) aged 12-17 years were analysed: iron depletion was found in $17.6 \%$ of the adolescents in Europe - with $21 \%$ in girls being significantly higher than $13.8 \%$ in boys $(\mathrm{p}<0.05)$. Iron deficiency was demonstrated in $5.4 \%$ of the girls and $3.9 \%$ of the boys. Iron depletion in adolescents in Germany and Austria was found in $16 \%$ and $19 \%$ of those tested respectively. It is of note that the highest prevalence of iron depletion was found with $43 \%$ of girls in Ireland and 16\% of boys in Denmark.

Recommendation: With respect to the cognitive function in children and adolescents, an adequate intake of iron-containing foods (e.g. meat, fish, poultry) should be ensured as a matter of principle in accordance with the FKE concept of an optimally balanced diet. Following a medical check-up with laboratory testing (e.g. ferritin, CRP, liver function tests, soluble transferrin receptors), regular iron supplements in an easily bioavailable form can be recommended for those in risk groups, such as girls with a higher iron requirement due to the onset of menstrual bleeding or young people, who are vegetarians.

\section{$B$ vitamins and a healthy nervous system}

The $\mathrm{B}$ vitamins work closely together supporting various bodily functions. Vitamin $B_{1}$, vitamin $B_{2}$ and vitamin $B_{12}$ are important for mitochondrial energy metabolism, acting in the production of cell energy in the form of ATP. Folic acid and vitamin $B_{12}$ are involved mainly in the processes of cell division and new cell formation (e.g. blood cells, mucosa). Together with vitamins $\mathrm{B}_{2}$ and $\mathrm{B}_{6}$, folic acid and $B_{12}$ are absolutely essential for the normal functioning of the nervous system and cognitive function. The synthesis of neurotransmitters (e.g. serotonin, dopamine) and the integrity of the myelin sheath surrounding nerve fibres depend on an adequate supply of these $B$ vitamins.

According to the results of the National Consumption Survey II, $78 \%$ of the girls and $66 \%$ of the boys aged between 14 and 18 years do not achieve the recommended daily intake of folic acid ( $400 \mu \mathrm{g}$ dietary folate). The average daily intake of dietary folate in young women is only $252 \mu \mathrm{g} .8 \%$ of young men and $33 \%$ of young women aged $14-24$ years do not achieve the recommended daily intake of vitamin $B_{12}$ [15]. A recent multicentre study on 1051 European adolescents (age: 12.5-17.5 years) recorded the dietary intake of $B$ vitamins on the basis of the folic acid, vitamin $B_{6}$ and vitamin $B_{12}$ levels in the blood as well as the plasma homocysteine concentrations. The average vitamin $B_{12}$ level in serum was $319 \mathrm{pmol} / \mathrm{L}(=432 \mathrm{pg} / \mathrm{mL}) .5 \%$ had an inadequate intake of vitamin $B_{12}$ based on the holotranscobalamin levels (an early marker of $B_{12}$ deficiency), $10 \%$ had an inadequate intake of folic acid based on the red blood cell folic acid concentration and $20 \%$ had an inadequate intake of vitamin $\mathrm{B}_{6}$ as shown by the pyridoxal 5-phosphate concentrations. $5 \%$ of the adolescents studied had raised plasma homocysteine levels. This shows that there is risk of folic acid, vitamin $\mathrm{B}_{6}$ and $\mathrm{B}_{12}$ deficiencies with pathological levels due to the poor nutrition provided by the regular diet of a considerable number of people.

The serum vitamin $B_{12}$ concentration is a later, relatively insensitive and non-specific biomarker of $B_{12}$ deficiency. A functional vitamin $B_{12}$ deficiency cannot be ruled out even with values of $<450 \mathrm{pg} / \mathrm{mL}$. With serum $B_{12}$ levels of $<450 \mathrm{pg} / \mathrm{mL}$, non-specific neurological symptoms of $B_{12}$ deficiency may already occur. In contrast, holotranscobalamin (holoTC), also called known as active $B_{12}$, is the earliest laboratory 
Table 2. Effects of multivitamin preparations on cognitive function in children and adolescents - a selection [20-25].

\begin{tabular}{|c|c|c|c|c|}
\hline Age ( \pm years $)$ & Number & Intervention (per day) & Duration & Cognitive effects \\
\hline 14 years & 615 & $\begin{array}{c}5000 \mathrm{IU} \text { Vitamin A (VA), } 1.5 \mathrm{mg} \text { VB1, } 1.7 \mathrm{mg} \\
\text { VB2, } 20 \mathrm{mg} \text { VB3, } 10 \mathrm{mg} \text { VB5, } 2 \mathrm{mg} \text { VB6, } 300 \\
\mu \mathrm{g} \text { biotin, } 400 \mu \mathrm{g} \text { folic acid, } 6 \mu \mathrm{g} \text { VB12, } 60 \mathrm{mg} \\
\text { VC, } 400 \mathrm{IU} \text { VD, } 30 \mathrm{IU} \mathrm{VE}, 50 \mu \mathrm{g} \text { VK, } 200 \mathrm{mg} \\
\mathrm{Ca}, 2 \mathrm{mg} \mathrm{Cu}, 0.10 \mathrm{mg} \mathrm{Cr}, 18 \mathrm{mg} \mathrm{Fe}, 150 \mu \mathrm{g} \mathrm{I} \\
80 \mathrm{mg} \mathrm{Mg}, 2.5 \mathrm{mg} \mathrm{Mn}, 0.25 \mathrm{mg} \mathrm{Mo}, 100 \mu \mathrm{g} \\
\text { Se, } 15 \mathrm{mg} \mathrm{Zn}\end{array}$ & 13 weeks & $\begin{array}{l}\text { Positive effects of micronutrient supplements } \\
(100 \% \text { according to RDA) on nonverbal intelligence } \\
(\mathrm{p}=0.01)\end{array}$ \\
\hline 9.5 years & 30 & $\begin{array}{c}375 \mu \mathrm{g} \text { VA, } 3.9 \mathrm{mg} \text { VB1, } 5 \mathrm{mg} \text { VB2 }, 50 \mathrm{mg} \\
\mathrm{VB} 3,50 \mathrm{mg} \text { VB5, } 12 \mathrm{mg} \text { VB6, } 100 \mu \mathrm{g} \text { biotin, } \\
100 \mu \mathrm{g} \text { folic acid, } 10 \mu \mathrm{g} \mathrm{VB} 12,500 \mathrm{mg} \text { VC, } 3 \\
\mu \mathrm{g} \text { VD, } 70 \mathrm{IU} \text { VE, } 100 \mu \mathrm{g} \mathrm{VK} ; 100 \mathrm{mg} \mathrm{Ca}, 0.2 \\
\mathrm{mg} \mathrm{Cr}, 1.3 \mathrm{mg} \mathrm{Fe}, 50 \mu \mathrm{g} \mathrm{I}, 7.6 \mathrm{mg} \mathrm{Mg}, 1.5 \mathrm{mg} \\
\mathrm{Mn}, 0.1 \mathrm{mg} \text { Mo, } 10 \mathrm{mg} \mathrm{Zn}, 50 \mathrm{mg} \text { Bioflavo, } \\
70 \mathrm{mg} \text { choline bitartrate, } 30 \mathrm{mg} \text { inositol, } 10 \\
\text { mg PABA }\end{array}$ & 13 weeks & $\begin{array}{c}\text { Positive effects of micronutrient supplements on } \\
\text { nonverbal intelligence }(p=0.02)\end{array}$ \\
\hline 8.9 & 468 & $\begin{array}{c}750 \mu \mathrm{g} \text { VA, } 0.75 \mathrm{mg} \text { VB1, } 0.85 \mathrm{mg} \text { VB2 }, 10 \\
\mathrm{mg} \text { VB } 3,5 \mathrm{mg} \text { VB5, } 1 \mathrm{mg} \text { VB6, } 200 \mu \mathrm{g} \text { folic } \\
\text { acid, } 3 \mu \mathrm{g} \mathrm{VB} 12,40 \mathrm{mg} \mathrm{VC}, 20 \mathrm{mg} \text { VE, } 5 \mu \mathrm{g} \\
\mathrm{VD}, 50 \mu \mathrm{g} \mathrm{Cr}, 1 \mu \mathrm{g} \mathrm{Cu}, 9 \mathrm{mg} \text { Fe, } 1.25 \mu \mathrm{g} \mathrm{Mn} \\
0.12 \mu \mathrm{g} \mathrm{Mo}, 50 \mu \mathrm{g} \mathrm{Se}, 7.5 \mathrm{mg} \mathrm{Zn}\end{array}$ & 13 weeks & $\begin{array}{c}\text { Positive effects of micronutrient supplements on } \\
\text { nonverbal intelligence (2.5 IQ points; 95\% CI: } 1.85 \text {, } \\
2.15)\end{array}$ \\
\hline 8.7 & 396 & $\begin{array}{c}400 \mu \mathrm{g} \text { VA, } 1 \mathrm{mg} \text { VB6, } 150 \mu \mathrm{g} \text { folic acid, } 1.5 \\
\mu \mathrm{g} \text { VB12, } 45 \mathrm{mg} \mathrm{VC}, 10 \mathrm{mg} \text { Fe, } 5 \mathrm{mg} \mathrm{Zn}\end{array}$ & 52 weeks & $\begin{array}{l}\text { Positive effects of micronutrient supplements on } \\
\text { verbal learning and memory (effect strength } 0.23 \text {, } \\
99 \% \mathrm{CI} ; 0.01,0.46)\end{array}$ \\
\hline 9.2 & 569 & $270 \mu \mathrm{g} \mathrm{VA}, 5 \mathrm{mg} \mathrm{Fe}, 50 \mu \mathrm{g} \mathrm{I}, 5 \mathrm{mg} \mathrm{Zn}$ & 31 weeks & $\begin{array}{l}\text { Positive effects of micronutrient supplements on } \\
\text { visual memory }(0.5 \text { points more; } 95 \% \mathrm{CI} ; 0.1,0.9)\end{array}$ \\
\hline 13 & 167 & $\begin{array}{c}5000 \mathrm{IU} \text { VA, } 1.5 \mathrm{mg} \mathrm{VB} 1,1.7 \mathrm{mg} \text { VB2}, 20 \mathrm{mg} \\
\text { VB3, } 2 \mathrm{mg} \text { VB6, } 400 \mu \mathrm{g} \text { folic acid, } 6 \mu \mathrm{g} \text { VB12, } \\
60 \mathrm{mg} \text { VC, } 400 \mathrm{IU} \mathrm{VD}, 15 \mathrm{IU} \text { VE, } 1.6 \mathrm{mg} \mathrm{Ca}, \\
2 \mathrm{mg} \mathrm{Cu}, 18 \mathrm{mg} \mathrm{Fe}, 25 \mathrm{mg} \mathrm{Mg}, 1 \mathrm{mg} \mathrm{Mn}, 10 \\
\mathrm{mg} \mathrm{Zn}\end{array}$ & 22 weeks & $\begin{array}{l}\text { Positive effects of micronutrient supplements on } \\
\text { non-verbal intelligence in adolescents with an } \\
\text { unhealthy diet }(<50 \% \text { der RDA })(p<0.02)\end{array}$ \\
\hline
\end{tabular}

parameter to reveal $\mathrm{B}_{12}$ deficiency [16]. In older people, raised homocysteine levels induced by vitamin $B_{12}$ deficiency are a significant risk factor for neurodegenerative diseases (e.g. dementia) and correlate strongly with atrophy in the frontal, parietal and occipital regions of the brain. Lowering these elevated homocysteine levels by the administration of B vitamins reduces the incidence of cerebral atrophy in patients with mild cognitive impairment.

Plasma homocysteine levels are inversely proportional to the folic acid levels in the blood. The reason for this is the inadequate provision of methyl groups through 5-methyltetrahydrofolate (5-MTHF) in the case of folic acid deficiency; these methyl groups are required for the remethylation of homocysteine to L-methionine. Gene polymorphism of 5-MTHF reductase is often a contributary factor here. Studies on adolescents show an inverse correlation of the body weight and body mass index (BMI) with the folic acid and vitamin $\mathrm{B}_{12}$ status. One study on 60 children and adolescents aged 7 to 17 years found significantly higher homocysteine levels in the overweight subjects than in those of normal weight $(14.3 \pm 11.8 \mu \mathrm{mol} / \mathrm{L}$ vs $8.7 \pm 5.9 \mu \mathrm{mol} / \mathrm{L}, \mathrm{p}=0.017)$ [17]. In short-term interventional studies on preschool children, folic acid, vitamin $\mathrm{B}_{2}, \mathrm{~B}_{6}$ and $\mathrm{B}_{12}$ supplements lowered the plasma homocysteine levels and improved folic acid balance. On the other hand, there was no improvement in the cognitive function of these children.

Recommendation: With respect to cognitive function in adolescents, an adequate intake of folic-acid-containing foods (e.g. vegetables, fruit, pulses) should be ensured as a matter of principle in accordance with the FKE concept of an optimally balanced diet. Additional folic acid, vitamin $\mathrm{B}_{6}$ and $\mathrm{B}_{12}$ supplements in physiological doses are to be recommended in risk groups, such as girls regularly taking oral contraceptives. Children brought up on a vegan diet cannot obtain an adequate supply of vitamin $B_{12}$ unless they are given nutritional supplements.

\section{Antioxidants: Vitamin C, vitamin E \& co.}

Especially during childhood and adolescence, an adequate nutritional status of antioxidant vitamins (e.g. vitamin C, E) and carotenoids is essential because of its importance for cell growth and cell development. In addition, various neuroprotective effects have been ascribed to vitamin E. According to the results of the National Consumption Survey II, $29 \%$ of the girls and $32 \%$ of the boys aged between 14 and 18 years do not achieve the recommended daily vitamin C intake of $100 \mathrm{mg}$. In addition, $48 \%$ of young men and $49 \%$ of young women aged 14-24 years do not achieve the recommended daily intake of $15 \mathrm{mg}$ vitamin E. A recent multicentre study on 1054 European adolescents (age: 12.5-17.5 years) recorded the dietary intake of antioxidant vitamins on the basis of the vitamin $\mathrm{C}$, vitamin $\mathrm{E}$, vitamin $\mathrm{A}$ and beta-carotene levels in the blood. The average vitamin E concentration was $23 \mu \mathrm{mol} / \mathrm{L}$ and the vitamin $\mathrm{C}$ concentration $59 \mu \mathrm{mol} / \mathrm{L}$. From the point of view of prevention, the intake of these antioxidant vitamins can be considered suboptimal. In the prevention of cardiovascular disease and cancer, every effort should be made to achieve vitamin $C$ levels of $\geq 70 \mu \mathrm{mol} / \mathrm{L}$ and vitamin $\mathrm{E}$ levels of $>30 \mu \mathrm{mol} / \mathrm{L}$. The regular consumption of antioxidant-rich fruit and vegetables should easily provide these preventative plasma concentrations. In addition, epidemiological studies and prospective case-control studies have yielded evidence that eating more fruit and vegetables reduces the risk of cognitive impairment $[18,19]$.

Recommendation: The FKE concept of an optimally balanced diet basically considers that adolescents should, as a matter of principle, have an adequate intake of antioxidant-rich foods (e.g. fresh fruit, vegetables). They should eat at least $300 \mathrm{~g}$ fresh fruit and $300 \mathrm{~g}$ fresh vegetables daily. 


\section{Multivitamins and scholastic performance - a selection}

Various studies on children and adolescents have achieved an improvement in cognitive function (e.g. attention, memory, concentration, nonverbal intelligence, verbal learning) with the regular administration of multivitamin/mineral supplements (Table 2).

\section{Conclusion}

With respect to scholastic performance, children and adolescents with unhealthy eating habits will particularly benefit from nutritional supplements. But it is only worthwhile, if these products are taken regularly and consistently for several weeks.

\section{References}

1. Gruber K (2011) Im Blickpunkt: Symposium "Kinderernährung - Mythen versus Wissenschaft", Journal für Ernährungsmedizin 13: 6-10.

2. Diethelm K, Jankovic N, Moreno LA (2012) Food intake of European adolescents in the light of different food-based dietary guidelines: results of the HELENA (Healthy Lifestyle in Europe by Nutrition in Adolescence) Study. Public Health Nutr 15: 386398. [Crossref]

3. Kersting M, Alexy U, Schürmann (2016) Critical Dietary Habits in Early Childhood: Principles and Practice. World Rev Nutr Diet 115: 24-35. [Crossref]

4. Yau PL, Castro MG, Tagani A, Tsui WH, Convit A, et al. (2012) Obesity and metabolic syndrome and functional and structural brain impairments in adolescence. Pediatrics 130: e856-e864. [Crossref]

5. Beiner J (2011) Jugendliche verzehren mehr Alkohol als Gemüse. Die Welt online.

6. Holick MF. Vitamin D deficiency. N Engl J Med 357: 266-281.

7. Grant WB, Wimalawansa SJ, Holick MF (2015) Emphasizing the Health Benefits of Vitamin D for Those with Neurodevelopmental Disorders and Intellectual Disabilities. Nutrients 7: 1538-1564. [Crossref]

8. Holick MF (2015) Vitamin D and brain health: the need for vitamin D supplementation and sensible sun exposure. J Intern Med 277: 90-93.

9. Grober U, Holick MF (2020) Vitamin D: Die Heilkraft des Sonnenvitamins. 4., erweiterte und aktualisierte Auflage, 490 S., Wissenschaftliche Verlagsgesellschaft, 2020.

10. Straßburg A, Eisinger-Watzl M, Krems C (2019) Comparison of Food Consumption and Nutrient Intake Assessed with Three Dietary Assessment Methods: Results of the German National Nutrition Survey II. Eur J Nutr 58: 193-210.
11. Stonehouse W (2014) Does consumption of LC omega-3 PUFA enhance cognitive performance in healthy school-aged children and throughout adulthood? Evidence from clinical trials. Nutrients 6: 2730-2758. [Crossref]

12. Chang JPC, Su KP, MOndelli V, Pariante CM (2018) Omega-3 Polyunsaturated Fatty Acids in Youths with Attention Deficit Hyperactivity Disorder: A Systematic Review and Meta-Analysis of Clinical Trials and Biological Studies. Neuropsychopharmacology 43: 534-545.

13. Larson LM, Phiri KS, Pasricha SR (2017) Iron and Cognitive Development: What Is the Evidence? Ann Nutr Metab 71: 25-38. [Crossref]

14. Ferrari M, Mistura L, Patterson E (2011) Evaluation of iron status in European adolescents through biochemical iron indicators: the HELENA Study. Eur J Clin Nutr 65: $340-349$.

15. González-Gross M, Benser J (2012) Gender and age influence blood folate, vitamin B12, vitamin B6, and homocysteine levels in European adolescents: the Helena Study. Nutr Res 32: 817-826.

16. Gröber U, Kisters K, Schmidt J (2013) Neuroenhancement with Vitamin B12: Underestimated neurological significance. Nutrients 5: 5031-5045. [Crossref]

17. Narin F, Atabek ME, Karakukcu M (2011) The association of plasma homocystein levels with serum leptin and apolipoprotein B levels in childhood obesity. Ann Saudi Med 25: 209-214. [Crossref]

18. Breidenassel C, Valtueña J, González-Gross M (2011) Antioxidant vitamin status (A, $\mathrm{E}, \mathrm{C}$, and beta-carotene) in European adolescents - the HELENA Study. Int J Vitam Nutr Res 81: 245-255.

19. Peneau S, Galan P, Jeandel C (2011) Fruit and vegetable intake and cognitive function in the SU.VI.MAX 2 prospective study. Am J Clin Nutr 94: 1295-1303.

20. Schoenthaler SJ, Bier ID, Young K (2000) The effect of vitamin-mineral supplementation on the intelligence of American schoolchildren: a randomized, double-blind placebocontrolled trial. J Altern Complement Med 6: 19-29. [Crossref]

21. Osendarp SJ, Baghurst KI, Bryan J (2007) Effect of a 12-mo micronutrient intervention on learning and memory in well-nourished and marginally nourished school-aged children: 2 parallel, randomized, placebo-controlled studies in Australia and Indonesia. Am J Clin Nutr 86: 1082-1093.

22. Manger MS, McKenzie JE, Winichagoon P (2008) A micronutrient-fortified seasoning powder reduces morbidity and improves short-term cognitive function, but has no effect on anthropometric measures in primary school children in northeast Thailand: a randomized controlled trial. Am J Clin Nutr 87: 1715-1722. [Crossref]

23. Benton D, Buts JP (1990) Vitamin/mineral supplementation and intelligence. Lance 335: $1158-1160$

24. Eilander A, Gera T, Sachdev HS (2010) Multiple micronutrient supplementation for improving cognitive performance in children: systematic review of randomized controlled trials. Am J Clin Nutr 91: 115-130. [Crossref]

Copyright: (C2020 Gröber U. This is an open-access article distributed under the terms of the Creative Commons Attribution License, which permits unrestricted use, distribution, and reproduction in any medium, provided the original author and source are credited. 